\title{
Improving Gross Motoric Skill of Early Childhood Through Dance Arts Learning
}

\author{
Yulia Purnamasari \\ Early Childhood Education Department, Padang State University, Padang, Indonesia, \\ yuliapurnamasari0207@gmail.com
}

\begin{abstract}
Young children need a fun exercise for their gross motoric skills. The type and nature of activities conducted should be attractive. It is expected that the overall developmental aspects are increased through the exercise. One of them is through dance. Learning the art of dance performed by teachers should pay attention to the basic elements of dance, both in intra and extra learning to optimize learning objectives. For children who have delay on gross motoric skills with the ability can be increased through this activities. Thus the findings obtained can be used as the control or supervision of the child to exercise gross motoric can be done for all children. This exercise improves basic motion ability of the children in order to improve the quality of life.
\end{abstract}

Keywords: Dance, Gross motoric skills, Childhood

\section{INTRODUCTION}

Early childhood education is one form of organization of education that focuses on the foundation towards growth and physical development (coordination of fine and gross motoric), intellect (the intellect, creativity, emotional intelligence, spiritual intelligence), social emotional (attitudes and behaviors), language and communication in accordance with the characteristics and development of children.

Early childhood is the golden era in human development throughout the age range. This Golden Age occurred in the age range of 0-6 years. At this time, the growth and development of children in various aspects is undergoing rapid development.

Early childhood in general please motion activity rhythmic or rhythmic and dynamic activity. They are happy to do the movements that follow the rhythm of the song or sing. Event dance movement can give an impulse or a good stimulus for the children in the process of building and finding their momentum. Children need to find the original motion so that it can express with the help of teachers to be creative in accordance with the wishes of his soul.

Preschool is the initial momentum to efforts intensive coaching, systematic, and professional. Preschool age is the age that determine the further growth and development. At this age, the basics of children's abilities and personality will be formed. If at this time the kids get the right education, it will form the foundations of a good personality and behavior are strongly attached. The golden age is crucial to lay the foundations of personality, which will give color when a child was to become an adult.

At this time of the initial formation of the basic ability of sensing, thinking ability, skill and moral growth and behavior, so that it can be said that the attitudes, habits, and behaviors that are formed during the early years of the child will determine how far someone managed to adapt in life when they adulthood.

Sensitive period is a period of the maturation of the functions of the physical and psychological ready to respond to the stimulus provided by the environment. "Golden age in motoric development is middle childhood or childhood. In early childhood, physical health began to stabilize and physical development of children to a maximum of the previous age.

Motoricic development include development of gross motoric and fine motoric skills. At the preschool physical movements were done not only to develop physical but can be a positive influence on children's self-esteem. Lack of fine motoric skills mastered child will affect the low income, the child is easily frustrated, desperate, and ultimately lazy boy doing other activities.

Child motoric skills vary, some are slow and some are in accordance with the development depends on the maturity of the child. Therefore, from an early age the child's motoric development aspects in the form of fun activities to stimulate the motoric development of children to the maximum especially fine motoric development of children. The activity was carried out by way of play, movement of the child's motoric will have positive impact on other aspects of development.

Delayed motoric development means the development of motoric under normal age of the child, resulting in a certain age children do not master the developmental tasks expected of her age group. Children who experience delays in the development of fine motoric having difficulty coordinating movement of the hand and fingers flexible fingers.

As for some of the factors that cause delays in the development of fine motoric skills of children such as lack 
of opportunity to explore the environment in infancy, not acustomed to work on his own activities so that children are accustomed always assisted to meet their needs. For example, the habit of wearing the clothes button himself, using his own shoes with shoelaces and so on. It will be its own quirks and indirectly fine motoric aroused. Children who are spending less time doing activities that use fine motoric could lead to less berkembangya smooth muscles of the hand.

\section{THEORETICAL REVIEW}

Early childhood education programs

Suryana (2017) said that the kindergarten into formal institutions that serve children aged four to six years with the aim to develop every aspect of the development of a wholly owned subsidiary through learning activities fun. Services every child's development made by educators and education personnel. Educators as a teacher is responsible for the development of the child in school.

Khairma and Dadan (2017) program structure early childhood education activities include the development of behavior formation and the development of basic abilities through play activities and habituation. The scope of development include: (a) the values of religion and morals, (b) physical, (c) cognitive, (d) languages, (e) social emotional and (f) art. The purpose of early childhood education is to develop a variety of potential children early in order to develop optimally according to the type of intelligence and readiness to enter further education.

An educator should be able to encourage and inspire students are able to understand, implement, and develop ways of thinking rationally and objectively in response to the substance or learning materials. According to Suryana (2017: 70) defined learning objectives in a simple and clear, yet attractive presentation system.Suyadin and Maulidya (2013) states the purpose of early childhood education is to provide stimulation or stimulus for the development of human potential in order that the child be faithful and devoted to God Almighty, noble, knowledgeable, skilled, critical, creative, innovative, independent, confident, and become citizens of a democratic and responsible.

\section{Early childhood}

Suryana (2013: 25) states that early childhood is the initial period of the most important and most fundamental throughout the range of human growth and development. Early childhood has unique characteristics because they are in the process of child development subsequent to the end of its development.

Theo and Martin in Suryana (2011) things that are important in the early years of early childhood, among others: (1) 3-year-old son was able to learn to play and talk; (2) children aged 3 to 4 years had a great curiosity, because of the freedom and the opportunity to observe, move and carry out exploration activities themselves and the environment should be given; (3) children aged 2 to 6 years old was delighted to recognize himself and the world that surrounds it. Because it introduces the names of objects in the house, in the yard, at school, it is appropriate at this age; (4) the child's character is formed through the activities and learn over a period of 3-6 years of age, the child moves on and often follow impulses, at this time a good time to develop a child's character.

\section{Arts Education}

Arts education is the most effective way to enhance creativity, arts education in addition be a means of affective education in terms of emotion and expression accommodate children. There are two different concepts of art education that is the first concept art in education meant as a process of enculturation (civilizing process conducted with an effort to pass or to instill the values of the older generation to the next).

Thus the art approach in education is an effort of educators to develop and preserve a variety of existing art to students. The second concept of education through art, that art education is obliged to direct the achievement of the objectives of general education that provides a balance of rational, emotional, intellectual.

\section{Dance}

Dance as an art form is a special activity that is not just an expression of motion yangemosional or express feelings in the form of motion without direction and purpose, but it is a stimulus that affects the nervous organ as an embodiment of human kinesthetic patterns that is constructive.

Dance movement can help improve kinesthetic intelligence early childhood, where dance can provide reinforcement concentration, flexibility and beauty of movement, not only in the mastery kinesthetic (psychomotoric) but it can provide and the opportunities acquired dance skills. Dance basic movements can be defined as the carnal movement that consists of their ideas, movement and rhythm to produce meaning.Tari is a type of art that is directly related to the motion of the human body, the body is a tool and gestures as a medium. Gestures that can be used as media in a dance which starts from head to toe movement through subtle movements (fine motoric) or coarse movement (gross motoric) (Rachmi 2008: 6.3).

Dance by Hidajat (2006: 56) is the art space of time. Dance includes three basic elements, namely the movement as a fundamental foundation that was formed when the movement which made it will be the formation of a space that is summed up in time. Learning the art of dance performed by teachers should pay attention to three basic elements of dance, both in intra and extra learning agartercapai optimal learning objectives. One of the basic elements of dance that is motion, motion beautiful on the dance instead of all the movements are realistic in life, but the movement has undergone a process of distortion and stylization that contains the beauty of the movement.

The basic elements of dance in addition to the motion, there is also room. The pattern of movement that occurs in the dance by Sundari (2009: 14) will form the aspects of space. Space for dancers by Widaryanto (2009: 42) uses horizontal stripes, diagonal and curved, carried out by the motion of both large and small volumes.

The room at the conceptual level by Hidajat (2006: 84 ) is known as a state that wadhag (physical material) and can be distinguished, has size and has range limitations, have weight and strength. Dance can be seen from the second element was mutual sustainable basis, in addition 
to the two basic elements of dance there is also a third that time.

All times are Murgiyanto in Wardani (2011: 17) is another element that concerns our lives every day. Dance is another element that occurs in time. This can be seen when the rhythmic body movements and beautifully done on time division neat.

Design your own space by Murgiyanto in Wardani (2011: 17) realized in dial-connect to form a "manifestation of the time" or sequence of motion. So that a movement which is summarized in the room can be strengthened by a series of time so that order may manifest in the dance. Hadi in Sundari (2009: 16) divide time into three aspects, namely: tempo, rhythm, and duration.

Preparation of dance by Hidajat (2006: 55) consider supporting elements as a construction material. Construction dance concepts can be called design, that is a pattern that embodies the "form", such as the design of floors, dramatic design, music design, makeup and clothing design, and layout design stage. From all these designs, the earliest step before the dance is staged in preparing the design of the floor. Floor design also called the pattern of the floor. Dance is not just a form of performance art, dance can also be taught to the next generation through education in the learning process. The material in learning the art of dance performed to form a dance movement that has aesthetic value.

\section{Learning Dance For Early Childhood}

Dance in the dimension of education will give color and direction of the formation of knowledge, attitude and movement skills. This is because learning dance is not only developing motoric competence alone, but affective and cognitive competence.

Socialization through dance will have an impact on self-esteem in children; (3) a vehicle for love of the environment. In addition to developing intellectual competence and social competence, dance education is also able to develop a love of the environment on children. This can be done by giving a sense of the meaning of the dance contained therein.

Thus the child is not only just memorized the dance but can instill an early age to love the natural environment; (4) the development of creativity. The development of this creativity can be done with motion exploration done by children. Through exploration of the children can try and find a wide range of motion desired.

\section{Motoric development of Early Childhood}

Motoric development is strongly influenced by the organs and functions of the central nervous system or the brain because of the central nervous system is very important in motoric skills and coordinate any movement the child. The maturity of the developing nervous system of the brain that govern child muscles allow the development of competence or ability of the child's motoric.

Gross motoric development model preschool / kindergarten, among others:

a. Bringing a child into a field that has a mound resembling a hill, expected that children would climb and descend continuously b. Ask your child to stand up while holding the ball, the ball is thrown up and the child was trying to recapture the ball

c. Make a line on the ground or floor measuring 20 $\mathrm{cm}$ in length of 4 meters or form plank, children are expected to walk forward and backward on the line

d. Provides the mine measuring 2 meters hanging in a buffer, it is expected the child to climb and hung a moment on the ropes

e. Make two lines of a width of $50 \mathrm{~cm}$ is like a ditch, crossed the line is expected that children with a way to skip the Basic Concepts Motion Capabilities basic motion is unusual ability students do in order to improve the quality of life.

f. The development of the motion control of the case in line with the physical growth, in the early days and the establishment of basic motion patterns. The basic movements include walking, running, jumping and leaping. Errors on the basic motion that is not corrected would be detrimental to the child and will be settled and difficult to be changed, such losses include: (1) not efficiency of movement, (2) poor mechanics at the time of appearance, (3) the likelihood of injury is greater, (4) a greater expenditure of energy / energy wastage and (5) of the achievements not optimal due to reduced quality of motion.

Basic motoric skills are divided into three categories: "Locomotoric, Non locomotoric, and manipulative. Locomotoric ability is used to move the body from one place to another or to lift himself up as: jump and jump. The ability of other movement is walking, running, skipping, jumping, sliding, and running like a galloping horse (gallop). Non locomotoric ability to do on-site, without adequate space.

Non locomotoric ability consists of bending and stretching, pushing and pulling, lifting and lowering, folding and twisting, churning, circular, toss and others. Manipulative skills developed as a middle child to master a variety of objects.

More manipulative skills involves the hands and feet, but other parts of the body can also be used. Object manipulation is far superior than the eye-foot coordination and hand-eye which is quite important for the item: walking (step movement) in the room. The forms of manipulative skills consist of: pushing motion (throwing, hitting, kicking).

\section{CONCLUSION}

Gross motoric development early childhood is as important as other aspects of development. If the child is not able to perform physical movements with good will foster insecurity and negative self-concept in performing physical movements.

Generally, children ages kindergarten is very active, they have a mastery of the body and particularly liked the activities done alone. Therefore, parents or teachers need to provide space and time for children to engage in activities that can train the muscles of rambunctious 
children and provide the goods and equipment for children that can be pushed, lifted, tossed or carry.

\section{REFERENCES}

[1] Hidajat, R. 2006. Menerobos Pembelajaran Tari Pendidikan. Malang: Banjar Seni Gantar Gumelar.

[2] Mansur. 2007. Pendidikan Anak Usia Dini Dalam Islam. Yogyakarta: Pustaka Pelajar.

[3] Mulyasa, E. 2012. Manajemen PAUD. Bandung: Remaja Rosdakarya Offset.

[4] Mulyasa. (2014). Pengembangan dan Implementasi Kurikulum 2013. Bandung: Remaja Rosdakarya.

[5] Sundari, Riris S. 2009. "Pengembangan Kepribadian dalam Pembelajaran Seni Tari di Kelompok Bermain dan Taman Kanak-Kanak $\mathrm{Hj}$. Isriati Baiturrahman 2 (Islamic Centre) Semarang", Skripsi Tidak Dipublikasikan. Semarang: UNNES.

[6] Suryana, dadan. 2013. Pendidikan Anak Usia Dini (Teori dan Praktik Pembelajaran). Padang: UNP Press.

[7] Suryana, Yulsyofriend. 2011. Pembelajaran Membaca Berbasis Teknologi Informasi di TK Pertiwi VI Kota Padang. Fakultas Ilmu Pendidikan Universitas Negeri Padang.

[8] Suryana, Dadan. 2017. Pengetahuan Tentang Strategi Pembelajaran, Sikap dan Motivasi Guru. Fakultas Ilmu Pendidikan Universitas Negeri Padang.

[9] Suryana, dadan. 2017. Pembelajaran Tematik Terpadu Berbasis Pendekatan Saintifik di Taman Kanak-kanak. Jurnal Pendidikan Usia Dini Volume 11 Edisi 1, April 2017.

[10] Suyadi dan Ulfah, Maulidya. 2013. Konsep Dasar Paud. Bandung: PT Remaja Rosdakarya.

[11]Wardani, Hamidah. 2011. "Pendekatan RME (Realistic Mathematics Education) dalam Pembelajaran Seni Tari pada Kegiatan Ekstrakurikuler di Taman Kanak-Kanak Al-Azhar 14 Semarang" Skripsi Tidak Dpiblikasikan. Semarang: UNNES.

[12] Widaryanto, F.X. 2009. Koreografi Bahan Ajar. Bandung: Jurusan Tari STSI Bandung. 